\title{
Explosive atmosphere ignition source identification during mining plant suspended monorail braking unit operation
}

\author{
Andrzej PYTLIK ${ }^{1}$, Jarostaw TOKARCZYK ${ }^{2}$, Witold FRAC $C^{3}$ and Dariusz MICHALAK ${ }^{4 *}$
}

Authors' affiliations and addresses:

${ }^{1}$ Department of Mechanical Devices Testing and Rocks, Central Mining Institute, plac Gwarków 1, 40-166 Katowice, Poland.

e-mail: apytlik@gig.eu

${ }^{2}$ Laboratory of Modelling Methods and Ergonomics, KOMAG Institute of Mining Technology, Pszczyńska 37, 44-101 Gliwice, Poland.

e-mail: jtokarczyk@komag.eu

${ }^{3}$ Department of Mechanical Devices Testing and Rocks, Central Mining Institute, plac Gwarków 1 , 40-166 Katowice, Poland.

e-mail:wfrac@gig.eu

${ }^{4}$ Laboratory of Modelling Methods and Ergonomics, KOMAG Institute of Mining Technology, Pszczyńska 37, 44-101 Gliwice, Poland.

e-mail:dmichalak@komag.eu

*Correspondence:

Dariusz Michalak, Laboratory of Modelling Methods and Ergonomics, KOMAG Institute of Mining Technology, Pszczynska 37, 44-101

Gliwice, Poland.

tel.: +48 322374362

e-mail: dmichalak@komag.eu

Funding information:

Funding Agency: Research Fund for Coal and Steel (RFCS)

Grant Number: 754169

\section{Acknowledgement:}

The paper was written as part of the work carried out under the European project INESI, "Increase efficiency and safety improvement in underground mining transportation routes". The project received funding from the Research Fund for Coal and Steel (RFCS) under grant agreement No. 754169. The calculations were carried out at the Academic Computer Centre in Gdańsk (Poland).

\section{How to cite this article:}

Pytlik, A., Tokarczyk, J., Frąc, W. and Michalak, D. (2021). Explosive atmosphere ignition source identification during mining plant suspended monorail braking unit operation. Acta

Montanistica Slovaca, Volume 26 (2), 338-351

DOI:

https://doi.org/10.46544/AMS.v26i2.12

\begin{abstract}
Coal dust and methane explosions are some of the most common causes of mining disasters in hard coal mines all over the world, and research continues to be conducted with the purpose of understanding the mechanisms of an explosion, explosion prevention and risk reduction. This article presents the test methodology as well as virtual and bench test results for a braking unit, which constitutes one of the main components of a suspended monorail transport system. The design work and virtual and bench testing were performed as part of a European research programme. The tests were conducted in a dedicated specialist test facility. The tests were based on Polish standard PN-G-46860:2011, concerning braking trolleys employed in mining plant suspended railway systems. The tests also factored in the requirements for nonelectrical devices intended for use in explosive atmospheres, including braking systems, as defined in standard PN-EN ISO 80079-36:2016, harmonised with the ATEX directive. The test scope encompassed braking unit operational component temperature measurements using thermal imaging and the contact method, as well as braking distance measurements. Further tests involved virtual simulations of brake pad heating. The tests employed the finite element method (time-varying calculations). Results obtained over the course of numerical calculations indicate that brief brake pad friction face heating, even up to a temperature exceeding $200^{\circ} \mathrm{C}$, does not result in inward heat propagation towards the brake pad material. This is also confirmed by the measurement results. However, under real conditions, the braking unit would be engaged only during an emergency situation, which would not lead to exceeding the permissible brake shoe material temperature values.
\end{abstract}

\section{Keywords}

suspended monorail, braking, bench testing, numerical tests, ATEX Directive, maximum brake shoe temperature.



(C) 2021 by the authors. Submitted for possible open access publication under the terms and conditions of the Creative Commons Attribution (CC BY) license (http://creativecommons.org/licenses/by/4.0/). 


\section{Introduction}

The mining of hard coal deposits under the conditions of constantly increasing extraction depth and concentration of coal faces is one of the key reasons for the rising absolute methane emission rates and coal seam methane pressure (Brune, 2013). It has a direct influence on the increase in methane explosion hazards in underground workings. Coal dust and methane explosions are some of the most common causes of mining disasters in hard coal mines all over the world, and research continues to be conducted with the purpose of understanding the mechanisms of an explosion, explosion prevention and risk reduction (Burtan et al., 2017), (Cioca \& Moraru, 2012), (Cybulski et al., 2018), (Górny, 2013), (Górny, 2017), (Hao et al., 2014), (Hudeček et al., 2012), (Jura et al., 2014), (Kałuża, 2017), (Krause \& Skiba, 2014). Broad studies have been conducted in Poland and worldwide for many years in order to reduce the risk of methane and coal dust explosion, with the intent of developing methods for explosion mechanism identification and prevention, and protection standards. The introduction of electrical equipment into mining plants in 1870 necessitated the commencement of research on explosion hazards (Krause \& Smoliński, 2013). It should be noted that the first studies on the parameters that determine methane ignition were conducted in Germany as early as 1884-1885, whereas the first fireproof shield tests were carried out at the University of Sheffield. This work resulted in regulations and standards being issued in countries such as Germany and the United Kingdom. The first standards organisation with an international reach was the International Electrotechnical Commission (IEC), established in 1906. In Poland, the first standard concerning explosion-proof equipment was issued in 1929 by the Association of Polish Electrical Engineers (Stowarzyszenie Elektryków Polskich, SEP), in cooperation with the Czechoslovakian Electrotechnical Association (Elektrotechnický Svaz Československý, ESČ). The Experimental Mine "Barbara", a part of the Central Mining Institute in Poland, has 95 years of experience in research on issues such as machines, equipment and materials employed in mining plants, as well as on phenomena related to gas and coal dust explosion. The testing grounds of Experimental Mine "Barbara" constitute the only site in Europe that is capable of supporting full-scale gas and dust explosion tests.

In order to standardise the regulations concerning basic requirements for equipment intended for use in explosive atmospheres, European Union member states adopted the ATEX directive. Before a device is permitted for use in the field, it is important to carry out a conformity assessment process, part of which involves tests for conformity with standards harmonised with the ATEX directive (Kuric, I. et al., 2019). Should there be no harmonised standards, the required tests and extent of testing are determined by a body notified within the scope of the directive, and, some of the basic certification tests include maximum temperature determination and potential methane and coal dust ignition source identification (PN-EN ISO 80079-36:2016-07). The ATEX directive encompasses requirements for both electrical and non-electrical devices. Unlike electrical device standardisation, the standardisation of non-electrical devices is a relatively recent endeavour, and its greatest development began with the adoption of the ATEX directive in 1994 (PN-G 46860:2011).

This article presents the test methodology as well as virtual and bench test results for a braking unit, which constitutes one of the main components of a suspended monorail transport system (Fig. 1).



Fig. 1. Suspended monorail transport system components

The tests were based on Polish standard PN-G 46860:2011, concerning braking trolleys employed in mining plant suspended railway systems (PN-G-46867:2007). The tests also factored in the requirements for nonelectrical devices intended for use in explosive atmospheres, including braking systems, as defined in standard PN-EN ISO 80079-36:2016, harmonised with the ATEX directive.

The primary test work was aimed at inspecting the influence of greater suspended monorail travel speed, increased from 2 to $5 \mathrm{~m} / \mathrm{s}$, on occupational safety (Akatov et al., 2019). For this purpose, a series of tests were carried out on the monorail drive equipment and braking systems, the cabin construction, the track and the hoists and roof support elements that interact with it (Pytlik, 2019).

The braking unit tests were conducted at a specialist test stand located at the Central Mining Institute. The test scope encompassed measurements of braking distance and static braking force as well as operational component temperature, performed using thermal imaging and the contact method. Further tests involved virtual simulations of brake pad heating (Pástor et al., 2020). The tests employed the finite element method (timevarying calculations). 


\section{Braking trolley test stand}

\section{Material and Methods - Bench testing}

The test stand (Fig. 2) is comprised of a $3 \mathrm{~m}$ - diameter flywheel with an $8 \mathrm{~mm}$ - thick ring gear. The wheel is driven by belt transmission. The braking unit is mounted in the test stand frame between a clamp holder and a braking force sensor with a measuring accuracy of $\pm 1 \%$. The rotational speed of a measuring point on the flywheel is measured by an optical sensor with an accuracy of $\pm 0.2 \mathrm{~mm} / \mathrm{s}$, placed on the wheel's drive shaft axle. The pressure drop in the braking system was also measured during the tests (with an accuracy of $0.5 \%$ ) using a strain gauge pressure sensor. All the measuring sensors were connected to a measuring amplifier, and the measurement values were registered with a measuring frequency of $1200 \mathrm{~Hz}$.



The test stand enables braking system testing at various flywheel energy, thanks to the possibility of adding or removing steel sheets from its frame. The braking force, distance and time tests involved a monorail trolley (Fig. 3) with braking systems (henceforth referred to as "braking unit") with a nominal static braking force of Fsmin $=60 \mathrm{kN}$.



Fig. 3. Diagram of a monorail trolley with a twin braking system: left $(L)$ and right $(R)$ pair of brake shoes

The diameter of a single brake shoe at the contact point with the track is approx. $66 \mathrm{~mm}$, therefore the contact surface is approx. $3421 \mathrm{~mm}^{2}$. The braking units can be employed in suspended monorail systems used for machine element, material and personnel transport in underground mining plants, in zones with and without methane presence, in workings classified as having "a", "b", or "c"-level methane explosion risk (to a max of $1.5 \%$ ) or in workings classified as having "A" or "B"-level coal dust explosion risk (Shepherd et al., 1981). According to Polish legislation (Journal of Laws of the Republic of Poland, Warsaw, 26th October 2015, item 1702.), workings exhibiting methane presence are classified as:

1) at no risk of methane explosion, with "a"-level methane explosion risk, if there is no possibility of methane concentration in the air exceeding $0.5 \%$,

2) at risk of methane explosion, with "b"-level methane explosion risk, if there is no possibility of methane concentration in the air exceeding $1.0 \%$ under normal ventilation conditions,

3) at risk of methane explosion, with "c"-level methane explosion risk, if methane concentration in the air may exceed $1.0 \%$ even under normal ventilation conditions.

Monorail trolleys can travel on tracks constructed from I155 (I140E) and I140V95 sections, as well as on tracks constructed from I155 sections with a toothed rack and on other tracks of permissible types. The structural 
trolley solutions and the available traction options make it possible to carry out transportation on a track with an inclination of up to $\pm 30^{\circ}$.

The current Polish mining laws permit a maximum suspended monorail speed of $2 \mathrm{~m} / \mathrm{s}$ (when transporting personnel). However, the braking unit is designed for a maximum nominal speed of $5 \mathrm{~m} / \mathrm{s}$, though it is utilised only as an emergency or parking brake.

For the bench tests, a decision was taken to also inspect the braking unit operation at speeds exceeding the current travel speed requirements; therefore, the tests were conducted at speeds ranging from 3 to $5 \mathrm{~m} / \mathrm{s}$. The maximum brake pad temperature was registered for this purpose during testing by means of a high-speed thermal camera with a sampling frequency of $96 \mathrm{~Hz}$. A high-speed video camera was used to analyse the brake shoe operation, registering the test courses with a frequency of $300 \mathrm{~Hz}$.

The heating of brake shoes subjected to multiple braking tests was also inspected during testing in order to recreate a scenario corresponding to braking unit operation not only during emergency braking but also during manoeuvring - i.e. during regular monorail travel (Sága et al., 2019). Thermocouples were used for this purpose, embedded in the brake shoe friction lining material (sintered carbide in a copper matrix).

The article presents the results of double system testing. In order to inspect the operation of a braking unit with a single pair of brake shoes, the hydraulic system of the cylinders was cut off from the pump supply during the tests by means of a stop valve.

\section{Bench test methodology and scope}

In order to release the brake shoes, a pressure of approx. $14 \mathrm{MPa}$ was introduced into the hydraulic system before the tests.

The test was based on bringing the flywheel to specific linear velocities $v$ of about $3 \mathrm{~m} / \mathrm{s}$ and $5 \mathrm{~m} / \mathrm{s}$ and then braking with the braking unit by lowering the pressure to zero. This was accomplished by means of a solenoid valve utilised in the hydraulic supply system.

The following tests were performed in order to obtain a complete braking unit operational characteristic:

- left brake shoe pair (L) engaged at flywheel velocities of approx. $3 \mathrm{~m} / \mathrm{s}$ and $5 \mathrm{~m} / \mathrm{s}$,

- right brake shoe pair (R) engaged at flywheel velocities of approx. $3 \mathrm{~m} / \mathrm{s}$ and $5 \mathrm{~m} / \mathrm{s}$,

- left and right brake shoe pairs engaged at flywheel velocities of approx. $3 \mathrm{~m} / \mathrm{s}$ and $5 \mathrm{~m} / \mathrm{s}$.

The above brake shoe testing scope was carried out for a flywheel using 24 triangular steel sheets (the mass of each sheet was $45.5 \mathrm{~kg}$ ). This made it possible to test the braking system at the following values of kinetic energy:

- $\quad \mathrm{Ek}=2258 \mathrm{~J}$ at $\mathrm{v}=3.00 \mathrm{~m} / \mathrm{s}$,

- $\quad \mathrm{Ek}=6273 \mathrm{~J}$ at $\mathrm{v}=5.00 \mathrm{~m} / \mathrm{s}$.

The individual braking system tests were filmed using high-speed visual and thermal cameras. Before the tests, the flywheel track and the brake shoes were covered with a thin layer of special matt black varnish, resistant to high temperatures of up to $800{ }^{\circ} \mathrm{C}$. This enabled the observation of the brake shoes and the skid mark on the flywheel track and the determination of the thermal camera emissivity as a value of $\varepsilon=0.95$. The maximum brake shoe and track temperatures measured during the tests were referenced to the criterion value of Tmax $=150^{\circ} \mathrm{C}$, as defined in Polish standard PN-G 46860:2011 concerning braking trolleys and in standard PNEN ISO 80079-36:2016-07 harmonised with the ATEX directive. The determined maximum temperature concerns non-electrical equipment susceptible to the accumulation of coal dust under the conditions of a methane atmosphere.

Pictures of the brake shoes are provided in Fig. $4 \mathrm{a}$ and $4 \mathrm{~b}$. Fig. $4 \mathrm{c}$ presents a thermal image of a tested brake shoe during the inspection of thermal camera emissivity in a climatic chamber with a temperature of $100.0^{\circ} \mathrm{C}$. The maximum brake shoe temperature measurement accuracy was $\pm 2{ }^{\circ} \mathrm{C}$.



Fig. 4. Brake shoes: $a$ - before covering with varnish; $b$-after covering with matt black varnish; $c$ - when inspecting maximum temperature readouts for brake shoes covered with the black varnish 
A single thermocouple was introduced into each brake shoe in order to enable internal temperature variation identification. The thermocouple ends (measuring points) were located $2.4 \mathrm{~mm}$ away from the friction face. Pictures of the braking unit, brake shoes and flywheel track covered with matt black varnish are presented in Fig. 5.


Fig. 5. Braking trolley in the test stand with conduits guided from the thermocouples (a), and view of the brake shoe and track, covered with black varnish (b)

\section{Test results and discussion}

Tests using an immobile flywheel were performed in order to inspect the brake shoe pressure force applied to the track. Fig. 6 presents the characteristics of pressure force Fp measured for the left (L) and right (R) brake shoe pairs. Differences can be observed in terms of both the force Fp value and the increase of the load over time. The right brake shoe $(\mathrm{R})$ achieved a maximum pressure force of Fpmax $=70 \mathrm{kN}$, which constitutes approx. $10 \mathrm{kN}$ more compared to the left brake shoe (L). A more rapid right brake shoe pair force increase can also be observed, particularly within the time frames of $0-0.1 \mathrm{~s}$ and $0.1-0.2 \mathrm{~s}$.



Fig. 6. Left brake shoe (L); right brake shoe (R) Fp-brake shoe pressure force, $k N$

A compilation of bench test results using a moving flywheel is presented in Figs. 7-9 in the form of brake shoe temperature T characteristics as a function of time $t$.


Fig. 7. Brake shoe temperature T characteristics as a function of time t during braking tests with the left (L) brake shoe pair at velocities of $a-3 \mathrm{~m} / \mathrm{s}, b-5 \mathrm{~m} / \mathrm{s}$ 



Fig. 8. Brake shoe temperature T characteristics as a function of time t during braking tests with the right $(R)$ brake shoe pair at velocities of $a-3 \mathrm{~m} / \mathrm{s}, b-5 \mathrm{~m} / \mathrm{s}$

During tests at flywheel velocity of approx. $3 \mathrm{~m} / \mathrm{s}$, it was observed that the brake shoe temperature did not exceed $150^{\circ} \mathrm{C}$ for single brake shoe tests: the left brake shoe pair reached $\operatorname{Tmax}=132.0^{\circ} \mathrm{C}$, whereas the right brake shoe pair reached $\operatorname{Tmax}=119.4^{\circ} \mathrm{C}$. During tests at flywheel velocity of approx. $5 \mathrm{~m} / \mathrm{s}$, it was discovered that the brake shoe temperature exceeded $150^{\circ} \mathrm{C}$ for single brake shoe tests: the left brake shoe pair reached $\operatorname{Tmax}=154.4^{\circ} \mathrm{C}$, whereas the right brake shoe pair reached $\mathrm{Tmax}=171.3^{\circ} \mathrm{C}$. Mechanical sparking was witnessed during each test, which can be seen in the thermal images together with skid marks on the flywheel.


Fig. 9. Brake shoe temperature $T$ characteristics as a function of time $t$ during braking tests with the left and right $(L+R)$ brake shoe pairs at velocities of $a-3 \mathrm{~m} / \mathrm{s}, b-5 \mathrm{~m} / \mathrm{s}$

During tests with two brake shoe pairs $(\mathrm{L}+\mathrm{R})$ at flywheel velocities of about $3 \mathrm{~m} / \mathrm{s}$ as well as $5 \mathrm{~m} / \mathrm{s}$, it was observed that the brake shoe temperature did not exceed $150^{\circ} \mathrm{C}$ : at a velocity of $3 \mathrm{~m} / \mathrm{s}$ it reached $\mathrm{Tmax}=135.4^{\circ} \mathrm{C}$, and at $5 \mathrm{~m} / \mathrm{s}$ it reached $\mathrm{Tmax}=126.1^{\circ} \mathrm{C}$. Although it could be expected that the maximum temperature at a velocity of $5 \mathrm{~m} / \mathrm{s}$ would be greater than that at $3 \mathrm{~m} / \mathrm{s}$, after examining all the recorded data, the results were nevertheless deemed correct. In particular, the charts in Fig. 9a and $9 \mathrm{~b}$ demonstrate differences in temperatures that exceed $60^{\circ} \mathrm{C}$ for individual tests at similar braking times. Considerable differences in maximum temperatures and individual test courses can also be seen in the other charts depicting brake shoe temperature $\mathrm{T}$ characteristics as a function of time $t$ in Fig. 7 and Fig. 8. This is most likely due to the complex character of the dry friction between the brake shoes and the track, as well as due to the differences in the operation of both the brake shoe pairs. As has been demonstrated in the chart depicted in Fig. 6, the differences are related to both the brake shoe pressure force Fp applied to the flywheel track and the increase of the load over time. Analysis of the recordings registered by the high-speed camera revealed that the brake shoes achieved contact with the flywheel disc at various points in time while the tested braking unit began to vibrate. This phenomenon also had an influence on the braking force and distance courses (Fig. 14-17).

Characteristics of the measured internal brake shoe temperature $\mathrm{T}$ as a function of time $t$ are presented in Figs. 10-12. 




Fig. 10. Characteristics of internal brake shoe temperature T as a function of time t during braking tests with the left brake shoe pair



Fig. 11. Characteristics of internal brake shoe temperature T as a function of time $t$ during braking tests with the right brake shoe pair 




Fig. 12. Characteristics of internal brake shoe temperature $T$ as a function of time $t$ during braking tests with the left and right brake shoe pairs

Analysis of the internal brake shoe temperature variations demonstrates the influence of the brake pad pressure force applied to the flywheel track on the heating rate of a given brake shoe. The temperature increases more rapidly for the right brake shoe pair than for the left. On the other hand, the brake shoe cooling process was influenced by the halogen lighting on one side of the test stand (Kuric, 2011). The brake pads numbered 1 and 4 would heat up at a slower rate, which can be observed in the charts presented above. The influence of the linear velocity increase from 3 to $5 \mathrm{~m} / \mathrm{s}$ resulted in an average brake pad core temperature increase from 1 to $2^{\circ} \mathrm{C}$. Minor brake pad temperature increases during successive tests (in intervals of several minutes) at both $3 \mathrm{~m} / \mathrm{s}$ and $5 \mathrm{~m} / \mathrm{s}$ demonstrate that the braking system operation under emergency braking conditions does not influence either increased brake shoe wear or excessive brake shoe temperature increase. This is confirmed by the pictures in Fig. 13, presenting typical brake shoe wear and slight skid marks on the flywheel.


Fig. 13. Typical brake shoe wear (a) after all the tests, and flywheel track wear (b)

Typical braking system test courses at a kinetic energy of approx. $2258 \mathrm{~J}$ at $v=3 \mathrm{~m} / \mathrm{s}$ are shown in Fig. 14. Fig. 15 presents typical results recorded by a thermal camera, demonstrating maximum temperatures at the point of braking, and Fig. 16 depicts courses of force as a function of braking distance (until the flywheel is brought to a complete halt). 




a





b



C

Fig. 14. Typical courses of braking force F, pressure $p$ and linear velocity $v$ as a function of time $t$ during testing at kinetic energy Ek $=$ $2258 \mathrm{~J}(v=3 \mathrm{~m} / \mathrm{s}): a$-for the left brake shoe pair $L ; b$-for the right brake shoe pair $R ; c$-for both the brake shoe pairs $L+R$



Fig. 15. Typical maximum temperatures registered at the point of braking during testing at kinetic energy Ek $=2258 \mathrm{~J}(v=3 \mathrm{~m} / \mathrm{s}):$ a - for the left brake shoe pair $L ; b$-for the right brake shoe pair $R ; c$-for both the brake shoe pairs $L+R$



a


Fig. 16. Typical courses of braking force $F$ as a function of braking distance $s$ during testing at kinetic energy Ek $=2258 \mathrm{~J}(v=3 \mathrm{~m} / \mathrm{s}):$ a for the left brake shoe pair $L ; b$-for the right brake shoe pair $R$; $c$-for both the brake shoe pairs $L+R$

Typical braking system test courses at a kinetic energy of $6273 \mathrm{~J}(v=5 \mathrm{~m} / \mathrm{s})$ are shown in Fig. 17. Fig. 18 presents typical results recorded by a thermal camera, demonstrating maximum temperatures at the point of braking, and Fig. 19 depicts courses of force as a function of braking distance (until the flywheel is brought to a complete halt).

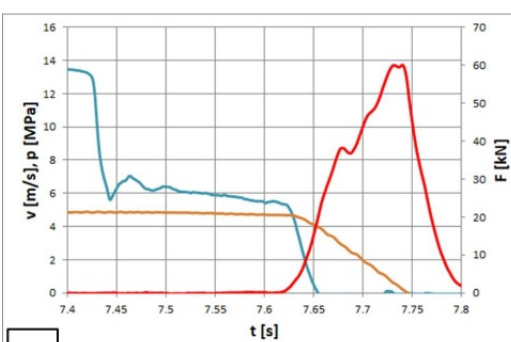

a



b



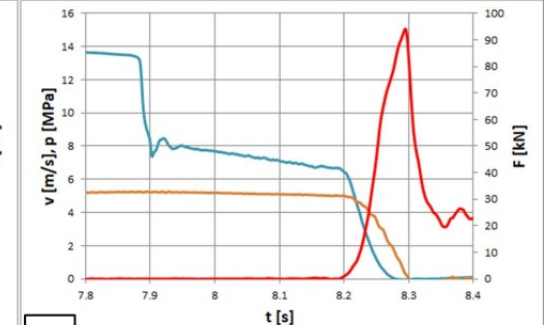

C - $\left.\mathrm{p}[\mathrm{MPa}]-\mathrm{v}[\mathrm{m} / \mathrm{s}]-\mathrm{F}_{\mathrm{fkN}}\right]$

Fig. 17. Typical courses of braking force F, pressure $p$ and linear velocity $v$ as a function of time $t$ during testing at kinetic energy Ek $=$ $6273 \mathrm{~J}(v=5 \mathrm{~m} / \mathrm{s}): a$-for the left brake shoe pair $L ; b$-for the right brake shoe pair $R$; $c$-for both the brake shoe pairs $L+R$ 




Fig. 18. Typical maximum temperatures registered at the point of braking during testing at kinetic energy Ek $=6273 \mathrm{~J}(v=5 \mathrm{~m} / \mathrm{s}):$ a - for the left brake shoe pair $L ; b$-for the right brake shoe pair $R ; c$-for both the brake shoe pairs $L+R$



Fig. 19. Typical courses of braking force $F$ as a function of braking distance s during testing at kinetic energy Ek $=6273 \mathrm{~J}(v=5 \mathrm{~m} / \mathrm{s}):$ a -

for the left brake shoe pair $L ; b$-for the right brake shoe pair $R ; c-$ for both the brake shoe pairs $L+R$

A test result compilation of average values derived from the maximum braking force is presented in Table 1 , whereas the results of average braking distance tests are presented in Table 2.

Table 1. Average maximum braking force values at various flywheel kinetic energies Ek

\begin{tabular}{|c|c|c|c|}
\hline \multirow{2}{*}{ Kinetic energy Ek } & \multicolumn{3}{|c|}{ Average braking force Favg [kN] } \\
\cline { 2 - 4 } & $\mathrm{L}$ & $\mathrm{R}$ & $\mathrm{L}+\mathrm{R}$ \\
\hline $2258[\mathrm{~J}]$ at $3[\mathrm{~m} / \mathrm{s}]$ & 41.9 & 67.5 & 55.1 \\
\hline $6273[\mathrm{~J}]$ at $5[\mathrm{~m} / \mathrm{s}]$ & 59.2 & 69.4 & 99.4 \\
\hline
\end{tabular}

Table 2. Average braking distance values at various flywheel kinetic energies Ek

\begin{tabular}{|c|c|c|c|}
\hline \multirow{2}{*}{ Kinetic energy Ek } & \multicolumn{3}{|c|}{ Average braking distance savg [mm] } \\
\cline { 2 - 4 } & L & R & L+R \\
\hline $2258[\mathrm{~J}]$ at $3[\mathrm{~m} / \mathrm{s}]$ & 186 & 181 & 179 \\
\hline $6273[\mathrm{~J}]$ at $5[\mathrm{~m} / \mathrm{s}]$ & 355 & 383 & 299 \\
\hline
\end{tabular}

The authors find it difficult to compare the data to results obtained by other scholars, as they have no knowledge of or access to test results in the form of publications.

\section{Numerical brake pad heating tests}

Numerical calculations with the application of the time-domain finite element method were performed simultaneously with the bench tests. The method is commonly employed to solve problems involving heat removal in braking system operational elements as well as processes leading to rolling element wear and tear (Journal of Laws of the Republic of Poland, Warsaw, 9th June 2017, item 1118.), (Takla \& Vavrusak, 1999), (Yuan, 2016). The purpose of the numerical tests was to assess heat propagation following the brief heating and cooling down to an ambient temperature of the brake pad friction face. The calculations were performed using the MSC.Marc/Mentat program (MSC.Software), (Yevtushenko \& Grzes, 2016), (Waddad et al., 2019), (Lian et al., 2019).

\section{Computational model}

A spatial geometric model of the braking unit was used to prepare the computational model, presented in Fig. 20. The computational model encompassed a fragment of one of the brake pads. 




Fig. 20. View of the spatial brake pad computational model finite element mesh

The following boundary conditions were defined:

- brake pad friction face heating characteristic (approx. $0.14 \mathrm{~s}-$ determined on the basis of bench tests), Fig. 21.

- thermal conductivity: $40 \mathrm{~W} /\left(\mathrm{m}^{*} \mathrm{~K}\right)$,

- $\quad$ specific heat: $444 \mathrm{~J} /(\mathrm{kg} * \mathrm{~K})$,

- density: $7800 \mathrm{~kg} / \mathrm{m} 3$,

- ambient temperature: $22.8^{\circ} \mathrm{C}$.



Fig. 21. Brake pad friction face heating characteristic

\section{Calculation results}

The numerical temperature calculation results are presented in Fig. 22. 




$0.2 \mathrm{~s}$



$1.0 \mathrm{~s}$



$2.0 \mathrm{~s}$



$0.5 \mathrm{~s}$



$1.5 \mathrm{~s}$



$2.5 \mathrm{~s}$

Fig. 22. Brake pad temperature following brief friction face heating after $0.2-2.5 \mathrm{~s}$

The course of heating and cooling for an area corresponding to the thermocouple location is presented on a chart (Fig. 23).



Fig. 23. Numerical simulation result. The course of brake pad internal temperature during brief friction face heating, measured at the thermocouple location

\section{Summary and conclusions}

The following conclusions can be drawn based on the courses of the braking force, pressure, distance and flywheel velocity registered during the braking unit tests performed at the Central Mining Institute's test facility:

- The average hydraulic braking system engagement time was approx. $0.2 \mathrm{~s}$ for a single brake shoe pair and $0.3 \mathrm{~s}$ for a double brake shoe pair.

- The greatest braking forces were registered when conducting double brake shoe tests at a kinetic energy of $6273 \mathrm{~J}$ at $\mathrm{v}=5 \mathrm{~m} / \mathrm{s}$. The average maximum braking force value for the aforementioned kinetic energy was $99.4 \mathrm{kN}$. 
- The shortest braking distances were registered for the double brake shoe pair at the same kinetic energy and corresponding velocity.

- Minor brake pad temperature increases during successive tests (in intervals of several minutes) at both $3 \mathrm{~m} / \mathrm{s}$ and $5 \mathrm{~m} / \mathrm{s}$ indicate that braking system operation under normal conditions - i.e. during emergency braking - has no influence on either increased brake shoe wear or on excessive brake shoe temperature increase.

- Testing at a flywheel velocity of approx. $5 \mathrm{~m} / \mathrm{s}$ revealed that the brake shoe temperature exceeded the value of $150^{\circ} \mathrm{C}$ during tests with a single brake shoe: left or right. The greatest temperature, $\operatorname{Tmax}=171.3^{\circ} \mathrm{C}$, was registered during a test of the single right brake shoe pair. Sparking that occurred during braking as a result of track surface abrasion by the brake shoes can be observed in thermal image charts. It should be noted that the operation of a single brake shoe pair was deliberate, and it does not occur under the conditions of normal braking unit operation.

- The lowest brake shoe temperatures were registered during the tests of both brake shoe pairs. This can be attributed to the increased brake shoe surface when using a double braking system compared to a single braking system. The pressure force distribution over double brake shoe pairs during the braking also has a beneficial influence on the decrease in the maximum temperature of the brake shoe-and-track assembly.

Furthermore, the results obtained over the course of numerical calculations indicate that brief (approx. 0.14 s long) brake pad friction face heating, even up to a temperature exceeding $200^{\circ} \mathrm{C}$, does not result in inward heat propagation towards the brake pad material. This is also confirmed by the measurement results presented in Fig. 9-11. However, under real conditions, the braking unit would be engaged only during an emergency situation, which would not lead to exceeding the permissible brake shoe material temperature values. It is significant that, based on the obtained results, the brake pad friction face cooling process is short, with reference to time intervals typical of their regular operation.

\section{References}

Akatov, N., Klačková, I., Mingaleva, Z., Galieva, G., Shaidurova, N. (2019). Expert technology for risk management in the implementation of QRM in a high-tech industrial enterprise, Management Systems in Production Engineering, 27, p.p. 250-254.

Brune, J. F. (2013). The methane-air explosion hazard within coal mine gobs. SME Transactions, 334, 376-390.

Burtan, Z., Stasica, J., \& Rak, Z. (2017). Wpływ katastrofogennych zagrożeń naturalnych na bezpieczeństwo pracy w górnictwie węgla kamiennego w latach 2000-2016 [The influence of natural hazards of disasters on the work safety conditions in Polish coal mining in the years 2000-2016]. Zeszyty Naukowe Instytutu Gospodarki Surowcami Mineralnymi i Energią PAN.

Cioca, I. L., \& Moraru, R. I. (2012). Explosion and/or fire risk assessment methodology: a common approach, structured for underground coalmine environments/Metoda szacowania ryzyka wybuchu i pożarów: podejście ogólne, dostosowane do środowiska kopalni podziemnej. Archives of Mining Sciences, 57(1), 53-60.

Cybulski, K., Dyduch, Z., Hildebrandt, R., \& Koptoń, H. (2018). Badania przebiegu wybuchów metanu w warunkach wyrobisk doświadczalnych GIG KD Barbara [Development of methane explosions in the underground experimental facilities of GIG EM Barbara]. Zeszyty Naukowe Instytutu Gospodarki Surowcami Mineralnymi i Energią PAN, 29-40. (in Polish).

Dziennik Ustaw Rzeczypospolitej Polskiej, Warszawa, dnia 26 października 2015 r., Poz. 1702. OBWIESZCZENIE MINISTRA ŚRODOWISKA z dnia 21 września 2015 r. w sprawie ogłoszenia jednolitego tekstu rozporządzenia Ministra Środowiska w sprawie zagrożeń naturalnych w zakładach górniczych [Journal of Laws of the Republic of Poland, Warsaw, 26th October 2015, item 1702. ORDINANCE OF THE MINISTER OF THE ENVIRONMENT of 21st September 2015 concerning the publication of the uniform text of the Ordinance of the Minister of the Environment concerning natural hazards in mining plants].

Dziennik Ustaw Rzeczypospolitej Polskiej, Warszawa, dnia 9 czerwca 2017 r., Poz. 1118. ROZPORZĄDZENIE MINISTRA ENERGII z dnia 23 listopada 2016 r. w sprawie szczegółowych wymagań dotyczących prowadzenia ruchu podziemnych zakładów górniczych [Journal of Laws of the Republic of Poland, Warsaw, 9th June 2017, item 1118. ORDINANCE OF THE MINISTER OF ENERGY of 23rd November 2016 concerning detailed requirements regarding underground mining plant operations].

Górny, M. (2013). Historia bezpieczeństwa przeciwwybuchowego w Polsce [The history of explosion-proof safety in Poland]. Bezpieczeństwo przeciwwybuchowe-wybrane zagadnienia. Praca zbiorowa. Główny Instytut Górnictwa, Katowice, 7-23. (in Polish). 
Górny, M. (2017). Ocena zagrożenia zapłonem części nieelektrycznej układu napędowego [Ignition risk assessment of nonelectrical part of drive system]. Napędy i Sterowanie, 19, Nr 10, 82-88. (in Polish).

Hao, F., Liu, M., \& Zuo, W. (2014). Coal and gas outburst prevention technology and management system for Chinese coal mines: a review. In Mine Planning and Equipment Selection (pp. 581-600). Springer, Cham.

Hudeček, V., Zapletal, P., Stoniš, M., \& Sojka, R. (2012). NEW RECOMMENDATIONS IN THE AREA OF PREDICTION AND PREVENTION OF ROCK AND GAS OUTBURSTS IN THE CZECH REPUBLIC. Rudarsko-Geolosko-Naftni Zbornik, 25.

Jura, B., Skiba, J., \& Wierzbinski, K. (2014). Applicability of surface directional wells for upper Silesia Basin coal seams' drainage ahead of mining. International Journal of Mining Science and Technology, 24(3), 353-362.

Kałuża, G. (2017). Pomiary temperatury w procesie badań urządzeń w wykonaniu przeciwwybuchowym [Temperature measurements in the process of testing explosion-proof devices]. Maszyny Elektryczne: zeszyty problemowe $\mathrm{Nr}$ 1/2017 (113), 85-89.

Krause, E., \& Skiba, J. (2014). Formation of methane hazard in longwall coal mines with increasingly higher production capacity. International Journal of Mining Science and Technology, 24(3), 403-407.

Krause, E., \& Smoliński, A. (2013). Analiza i ocena parametrów kształtujących zagrożenie metanowe w rejonach ścian [Analysis and assessment of methane hazard-producing parameters in longwall environments]. Journal of Sustainable Mining, 12(1).

Kuric, I. (2011). New methods and trends in product development and planning. 1st International Conference on Quality and Innovation in Engineering and Management (QIEM). Cluj Na-poca, 17.3.-19.3. 2011, p.p. 453-456, ISBN:978-973-662-614-2.

Kuric, I., Cisar, M., Tlach, V., et al. (2019). Technical Diagnostics at the Department of Automation and Production Systems. Book Series: Advances in Intelligent Systems and Computing, vol. 835, p.p. 474-484.

Lian Q., Deng G., Tieu A. K., Li H., Liu Z., Wang X., Zhu H. (2020). Thermo-mechanical coupled finite element analysis of rolling contact fatigue and wear properties of a rail steel under different slip ratios. Tribology International, Vol. 141, 105943. ISSN https://doi.org/10.1016/j.triboint.2019.105943, (http://www.sciencedirect.com/science/article/pii/S0301679X19304621)

Pástor, M., Živčák, J., Puškár, M., Lengvarský, P., Klačková, I. (2020) Application of Advanced Measuring Methods for Identification of Stresses and Deformations of Automotive Structures, In Journal; Applied Sciences, vol. 10 (21), article number 7510, MDPI, ISSN 2076-3417.

PN-EN ISO 80079-36:2016-07 — Explosive atmospheres — Part 36: Non-electrical equipment for explosive atmospheres - Basic method and requirements.

PN-G 46860:2011 - Kopalniane koleje szynowe - Wózki hamulcowe i urządzenia hamowania awaryjnego Wymagania [Mine railway systems - Braking trolleys and emergency braking devices - Requirements].

PN-G-46867:2007 - Kopalniane szynowe koleje linowe - Koleje podwieszone - Wymagania [Mine cable railway systems - Suspended railway - Requirements].

Pytlik A. (2019). Tests of steel arch and rock bolt support resistance to static and dynamic loading induced by suspended monorail transportation. Studia Geotechnica et Mechanica 41 (2), 81-92.

Sága, M., Vaško, M., Handrik, M., Kopas, P. (2019). Contribution to random vibration numerical simulation and optimisation of nonlinear mechanical systems, Scientific journal of Silesian University of Technology - Series Transport 103, p.p. 143-154.

Shepherd, J., Rixon, L. K., \& Griffiths, L. (1981, August). Outbursts and geological structures in coal mines: a review. In International Journal of Rock Mechanics and Mining Sciences \& Geomechanics Abstracts (Vol. 18, No. 4, pp. 267-283). Pergamon.

Takla, G., \& Vavrusak, Z. (1999). Coal Seam Gas Emissions from Ostrava-Karvina Collieries in the Czech Republic during Mining and after Mines Closure. In Coalbed Methane: Scientific, Environmental and Economic Evaluation (pp. 395-409). Springer, Dordrecht.

Yuan, L. (2016). Control of coal and gas outbursts in Huainan mines in China: A review. Journal of Rock Mechanics and Geotechnical Engineering, 8(4), 559-567.

MSC.Software: https://www.mscsoftware.com/product/marc

Yevtushenko A.A., Grzes P. (2016). Mutual influence of the sliding velocity and temperature in frictional heating of the thermally nonlinear disc brake. International Journal of Thermal Sciences, Vol. 102, 254262. ISSN 1290-0729. https://doi.org/10.1016/j.ijthermalsci.2015.11.021. (http://www.sciencedirect.com/science/article/pii/S1290072915003749)

Waddad Y., Magnier V., Dufrénoy P., De Saxcé G. (2019). Multiscale thermomechanical modelling of frictional contact problems considering wear - Application to a pin-on-disc system. Wear, Vol. 426-427, Part B, 1399-1409. ISSN 0043-1648, https://doi.org/10.1016/j.wear.2018.12.063, (http://www.sciencedirect.com/science/article/pii/S0043164818316673) 